\title{
China sets 2020 vision for science
}

\section{Goals include commercialization of research and emphasis on energy, biomedicine and information technology.}

\section{BY JANE QIU IN BEIJING}

$\mathrm{C}$ hina is betting that an ambitious programme of applied research will help to secure its future as an economic superpower. Innovation 2020, unveiled last week by the Chinese Academy of Sciences (CAS), maintains support for basic research. But the plan will place a new emphasis on translating the research into technologies that can power economic growth and address pressing national needs such as clean energy, said Bai Chunli, vice-president of the CAS, at the academy's annual conference in Beijing, where the plan was announced.

Innovation 2020 is an extension of the Knowledge Innovation Programme (KIP) launched by the CAS in 1998. Under the KIP, the academy streamlined its often overstaffed and outdated institutes, attracted outstanding Chinese researchers who had trained abroad, and tightened up the way it evaluated project proposals and performance. But the CAS now needs to support new priorities, says Duan Yibing, a policy researcher at the CAS Institute of Policy and Management in Beijing. China has become a global economic power, and the world's financial crisis has made scientific innovation more important to economic success than ever before, he says. "Things are a lot different now compared to 13 years ago."

Although the budget of Innovation 2020 is yet to be announced, insiders say it will be part of a continuing surge in the nation's science spending (see 'Spend, spend, spend'). Indeed,

\section{SPEND, SPEND, SPEND}

China's investment in science has risen rapidly over the past decade.

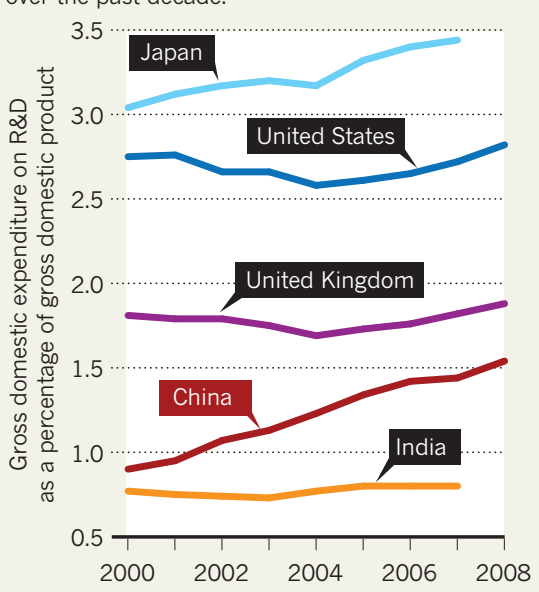

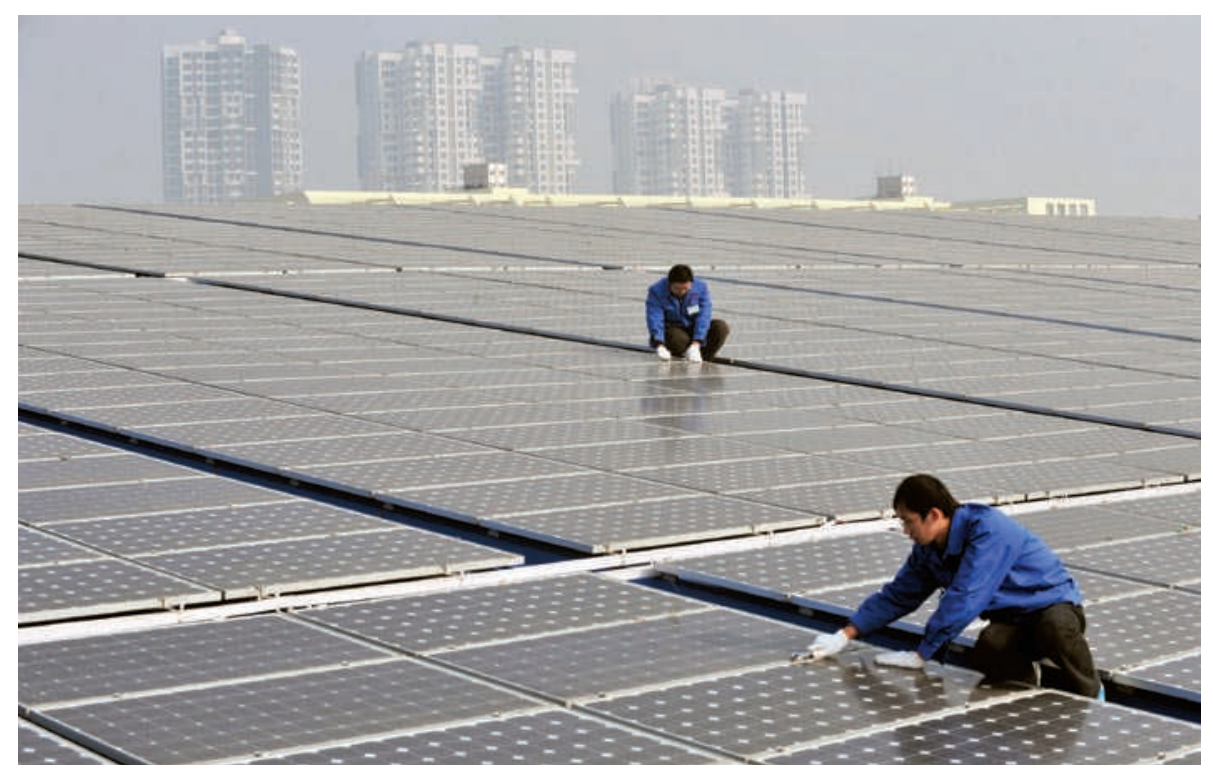

China is investing heavily in renewable-energy research as it builds its capacity in, for example, solar power.

the CAS's expenditure on research and development (R\&D) in 2009 was about 20 billion renminbi (US $\$ 3$ billion), seven times the level in 1998, according to a KIP assessment report also released last week. This year's budget for the National Natural Science Foundation of China will increase by $70 \%$, from 10 billion renminbi last year.

Innovation 2020 will kick off with new projects this year in seven key areas, including nuclear fusion and nuclear-waste management; stem cells and regenerative medicine; and calculating the flux of carbon between land, oceans and atmosphere. Other priority areas include materials science, information technology, public health and the environment.

To coordinate resources better and to foster multidisciplinary research, the academy will set up three research centres for space science, clean coal technologies and geoscience monitoring devices. It also plans to build three science parks - in Beijing, Shanghai and Guangdong province, respectively - to accelerate the conversion of basic research into marketable products, especially in renewable energy, information technology and biomedicine.

Pan Jiaofeng, deputy general secretary of the CAS, says the KIP's track record bodes well for the success of the new programme. By the CAS's reckoning, in 2009, researchers that it funded $\rightarrow$ NATURE.COM

For all the latest research from China, see:

www.nature.com/nchina published 3.5 times as many papers in journals listed by the Science Citation Index (SCI) as in 1998. Crucially, the number of papers published in the top $1 \%$ of SCI journals, as judged by their impact factor, was 12 times that in 1998. The CAS also calculates that research and development by the KIP generated an income of 140 billion renminbi and tax revenue of 22 billion renminbi in 2009 - respectively 19.5 and 14.5 times the levels in 2000.

But the report acknowledges that there is substantial room for improvement. For example, CAS researchers should aim to become leaders of the international scientific community, and shift their focus away from generating as many papers as possible and towards genuine originality and innovation.

With its emphasis on applied research, the new initiative also "presents a major challenge to the management and organizational capabilities of the academy", says Richard Suttmeier, a science-policy researcher at the University of Oregon in Eugene. He notes that most CAS institutes are focused on academic disciplines and lack the infrastructure needed for commercializing research or directing it towards national needs.

Others think that the emphasis on applied research, national needs and revenue could stifle curiosity-driven research. Without that, says a Shanghai-based researcher who declines to reveal his identity, "it would be very difficult to have genuine innovation". 